\title{
Diabetes in Pregnancy: Uterine Blood Flow and Embryonic Development in the Rat
}

\author{
PARRI WENTZEL, LEIF JANSSON, AND ULF J. ERIKSSON \\ Department of Medical Cell Biology, University of Uppsala, Biomedicum, Uppsala, Sweden
} \begin{abstract}
The uterine blood flow to individual implantation sites was
Thaluated in early normal and diabetic rat pregnancy, and related
evalus outcome. The aim was to search for a possible coupling between the flow rate and embryonic development. We studied pregnant rats of a malformation-prone Sprague-Dawley strain on gestational $\mathrm{d} 9,10,11$, and 12 , a time period which roughly corresponds to postconception wk 3-6 in human gestation. The blood flow in the uterus was estimated with the aid of a microsphere technique, and the embryos were evaluated with respect to morphology and uterine position. We found increased blood flow in the uterine and decidual tissue of the pregnant diabetic animals compared with normal pregnant rats on all days studied. The blood perfusion peaked on gestational d 10, both in normal and diabetic pregnancy. The implantations tended to be fewer,
\end{abstract}

whereas the resorption and malformation rates were higher, in the left horn than in the right horn. The blood flow in the uterine and decidual tissues was increased in the left horn in diabetic $\mathrm{d}$ 10 tissue, as well as d 12 tissues, thereby suggesting that compromised embryonic development is associated with increased rather than decreased supply of nutrients to the implantation site. These findings are in concert with previous in vitro results suggesting that enhanced oxidative stress due to increased substrate availability is an important factor in diabetic teratogenesis. (Pediatr Res 38: 598-606, 1995)

Abbreviations
MD rats and MD embryos, manifestly diabetic rats, and their
offspring
$\mathrm{N}$ rats and $\mathrm{N}$ embryos, normal rats and their offspring

Previous studies with placental scintigraphy in diabetic women have indicated decreased uteroplacental blood flow (1). The mechanism behind this reduction of the uterine blood flow is not known, but it has been speculated that the diameter of the uterine vessels supplying the placenta is slightly reduced, thereby restricting access of blood to the fetal-placental unit (2). The histologic structure of the placenta of the diabetic woman shows numerous changes (3), including increased villous branching and an increased total maternal-fetal exchange area (4-6). The latter alteration may be an effect of a compensatory mechanism for fetal nutrition, elicited by a decreased blood supply.

In diabetic rat pregnancy similar findings have been reported. Thus, decreased placental blood flow (7-9) and distorted placental morphology (10) have been found in diabetic rats at the end of pregnancy. In addition, changes in the capacity to transfer different nutrients from mother to fetus

Received November 1, 1994; accepted April 10, 1995.

Correspondence and reprint requests: Ulf J. Eriksson, M.D., Ph.D., Department of Medical Cell Biology, University of Uppsala, Biomedicum, P.O. Box 571, S-751 23 Uppsala, Sweden.

Supported by The Swedish Diabetes Association, The Bank of Sweden Tercentenary Foundation, The Expressen Prenatal Research Foundation, The Juvenile Diabetes Foundation International, The Novo Nordisk Foundation, The Swedish Society for Medical Sciences, The Ernfors Family Fund, and The Swedish Medical Research Council (Grant 12X-7475, 12P-9287). have been demonstrated in the chorioallantoic placenta of diabetic animals $(11,12)$. However, no study has been performed with the aim to investigate functional characteristics of the preplacenta (yolk sac) or early placenta in diabetic rats. Such parameters should be of paramount importance to establish, in particular in relation to the findings that congenital malformations are induced in early diabetic pregnancy (13), presumably before a time period corresponding to the 7 th wk of human gestation (14). Disturbances in the function of the preplacenta, rather than in the permanent chorioallantoic placenta, may conceivably affect the transfer of compounds between mother and embryo during a teratologically important period of pregnancy, and may thereby be involved in the teratogenic process.

One parameter of critical importance in an evaluation of the function of the preplacenta is the blood perfusion to the implantation site. The consequences for early embryonic development elicited by alterations in this blood flow are not yet fully explored. There are no reports of blood flow measurements performed during organogenesis with the intent to evaluate the role of uterine positions in diabetic rats. Furthermore, studies of the importance of uterine position for fetal weight have yielded very diverging results in normal rats (15-20), whereas the impact of diabetes on uterine vascular structure in early gestation has been previously investigated only in pseu- 
Table 1. Growth and development of embryos from $N$ and $M D$ pregnant rats on gestational $d$ 9-12, estimated as crown-rump length and number of somites, and expressed as mean \pm SEM.

\begin{tabular}{|c|c|c|c|c|c|}
\hline & $\begin{array}{c}\text { No. of } \\
\text { uterine } \\
\text { horns }\end{array}$ & $\begin{array}{c}\text { No. of } \\
\text { implantations }\end{array}$ & $\begin{array}{c}\text { No. of viable } \\
\text { offspring }\end{array}$ & $\begin{array}{l}\text { Crown-rump } \\
\text { length (mm) }\end{array}$ & No. of somites \\
\hline \multicolumn{6}{|l|}{$\mathrm{N} \mathrm{d} 9$} \\
\hline Right & 4 & 22 & 19 & $1.15 \pm 0.05$ & \\
\hline Left & 4 & 18 & 16 & $1.15 \pm 0.05$ & \\
\hline Total & 8 & 38 & 35 & $1.15 \pm 0.04$ & \\
\hline \multicolumn{6}{|l|}{$\mathrm{MDd} 9$} \\
\hline Right & 4 & 22 & 19 & $1.19 \pm 0.04$ & \\
\hline Left & 4 & 20 & 15 & $1.06 \pm 0.07$ & \\
\hline Total & 8 & 42 & 34 & $1.14 \pm 0.04$ & \\
\hline \multicolumn{6}{|l|}{$\mathrm{Nd} 10$} \\
\hline Right & 5 & 30 & 27 & $1.94 \pm 0.04$ & \\
\hline Left & 5 & 23 & 22 & $2.03 \pm 0.03$ & \\
\hline Total & 10 & 53 & 49 & $1.98 \pm 0.03$ & \\
\hline \multicolumn{6}{|l|}{$\mathrm{MD}$ d 10} \\
\hline Right & 4 & 22 & 17 & $1.59 \pm 0.07^{* * *}$ & \\
\hline Left & 4 & 19 & 11 & $1.38 \pm 0.07^{* * *}$ & \\
\hline Total & 8 & 41 & 28 & $1.51 \pm 0.05^{* * *}$ & \\
\hline \multicolumn{6}{|l|}{$\mathrm{N} \mathrm{d} 11$} \\
\hline Right & 4 & 24 & 24 & $4.28 \pm 0.10$ & $30.1 \pm 0.3$ \\
\hline Left & 4 & 22 & 19 & $4.24 \pm 0.21$ & $30.1 \pm 0.6$ \\
\hline Total & 8 & 46 & 43 & $4.27 \pm 0.10$ & $30.1 \pm 0.3$ \\
\hline \multicolumn{6}{|l|}{$\mathrm{MD} d 11$} \\
\hline Right & 5 & 27 & 22 & $3.86 \pm 0.11^{* * *}$ & $29.1 \pm 0.6$ \\
\hline Left & 5 & 29 & 24 & $3.60 \pm 0.14^{* * *}$ & $27.0 \pm 1.0$ \\
\hline Total & 10 & 56 & 46 & $3.73 \pm 0.09^{* * *}$ & $28.0 \pm 0.6$ \\
\hline \multicolumn{6}{|l|}{$\mathrm{N} \mathrm{d} 12$} \\
\hline Right & 5 & 32 & 31 & $6.38 \pm 0.11$ & $41.7 \pm 0.6$ \\
\hline Left & 5 & 24 & 23 & $6.75 \pm 0.10$ & $43.9 \pm 1.0$ \\
\hline Total & 10 & 56 & 54 & $6.54 \pm 0.07$ & $42.6 \pm 0.6$ \\
\hline \multicolumn{6}{|l|}{$\mathrm{MD} d 12$} \\
\hline Right & 4 & 28 & 20 & $5.60 \pm 0.24^{* * *}$ & $34.5 \pm 2.1^{* * *}$ \\
\hline Left & 4 & 21 & 17 & $5.64 \pm 0.18^{* * *}$ & $36.7 \pm 1.1^{* * *}$ \\
\hline Total & 8 & 19 & 37 & $5.62 \pm 0.15^{* * *}$ & $35.5 \pm 1.2^{* * *}$ \\
\hline
\end{tabular}

Significances:

${ }^{* * *} p<0.001$ vs $\mathrm{N}$ (two-tailed $t$ test).

do-pregnant rats (21). The aim of the present study was therefore to characterize the blood flow to the individual implantation site, and to search for a possible coupling to the embryonic outcome. In particular, we aimed to investigate the relation between blood flow and uterine location of the concepti with respect to congenital malformations and resorptions in early diabetic pregnancy.

\section{METHODS}

Animals. Embryos were obtained from normal and diabetic females of a local outbred Sprague-Dawley strain with an increased incidence of congenital malformations in diabetic pregnancy (22). Diabetes was induced with the aid of a single i.v. dose of streptozotocin $(40 \mathrm{mg} / \mathrm{kg})$ in a tail vein of virgin female rats weighing 250-300 g. One week after the injection the serum glucose concentration was estimated with a Glucose Analyzer 2 (Beckman Instruments, Fullerton, CA). Rats with a glucose concentration in excess of $20 \mathrm{mmol} / \mathrm{L}$ were considered to be $\mathrm{MD}$. Nondiabetic rats $(\mathrm{N})$ did not receive any injection and had a serum glucose concentration of 5-6 mmol/L. All rats were fed a commercial pelleted $\operatorname{diet}(\mathrm{AB}$ Analycen, Lidköping, Sweden) and had free access to food and tap water. They were maintained at an ambient temperature of $22^{\circ} \mathrm{C}$ with a $12-\mathrm{h}$ light/dark cycle. Female and male rats were caged together during the night. The morning that conception was verified by the presence of sperm in a vaginal smear was designated gestational $\mathrm{d} 0$.

Measurement of embryonic growth and development. On gestational d 9,10,11, or 12 the pregnant $\mathrm{N}$ and MD rats were killed by cervical dislocation, and the uterus was dissected out. Individual embryos were freed of their decidua and membranes and morphologically scored. The embryos were consecutively numbered within each uterine horn, starting from the position nearest to the ovary. At each position embryos were evaluated to be resorbed or viable. Embryos from gestational d 11 and 12 were judged with respect to developmental abnormalities. An embryo was judged to be either morphologically normal or having a malformation (mainly neural tube closure abnormalities or rotational defects). The crown-rump length was measured on embryos from gestational d 10-12, whereas the length of the whole egg cylinder including the ectoplacental cone was used as a measure of size of the $d 9$ embryos. In addition, the somite number was estimated on d 11-12 embryos. The protein and DNA contents were determined in 
Table 2. Growth and development of embryos $N$ and $M D$ pregnant rats on gestational $d 9-12$, estimated as embryonic contents of protein and DNA, and the protein/DNA ratio, expressed as mean $\pm S E M$

\begin{tabular}{|c|c|c|c|c|c|c|}
\hline & $\begin{array}{c}\text { No. of uterine } \\
\text { horns }\end{array}$ & $\begin{array}{c}\text { No. of } \\
\text { implantations }\end{array}$ & $\begin{array}{c}\text { No. of viable } \\
\text { offspring }\end{array}$ & Protein (mg) & DNA (mg) & $\begin{array}{c}\text { Protein/ } \\
\text { DNA }\end{array}$ \\
\hline \multicolumn{7}{|l|}{$\mathrm{N}$ d 9} \\
\hline Right & 4 & 22 & 19 & $91 \pm 10$ & $2.0 \pm 0.3$ & $48.9 \pm 2.0$ \\
\hline Left & 4 & 18 & 16 & $99 \pm 12$ & $2.1 \pm 0.3$ & $48.2 \pm 3.3$ \\
\hline Total & 8 & 38 & 35 & $94 \pm 8$ & $2.0 \pm 0.2$ & $49.2 \pm 1.7$ \\
\hline \multicolumn{7}{|l|}{ MD d 9} \\
\hline Right & 4 & 22 & 29 & $81 \pm 5$ & $1.5 \pm 0.1$ & $55.9 \pm 3.9$ \\
\hline Left & 4 & 20 & 15 & $76 \pm 9$ & $1.4 \pm 0.1$ & $52.8 \pm 3.8$ \\
\hline Total & 8 & 42 & 34 & $79 \pm 5$ & $1.5 \pm 0.1$ & $54.6 \pm 2.7$ \\
\hline \multicolumn{7}{|l|}{$\mathrm{Nd} 10$} \\
\hline Right & 5 & 30 & 27 & $94 \pm 6$ & $4.7 \pm 0.3$ & $20.6 \pm 0.9$ \\
\hline Left & 5 & 23 & 22 & $104 \pm 4$ & $5.0 \pm 0.2$ & $21.2 \pm 0.9$ \\
\hline Total & 10 & 53 & 49 & $99 \pm 4$ & $4.9 \pm 0.2$ & $20.9 \pm 0.7$ \\
\hline \multicolumn{7}{|l|}{ MD d 10} \\
\hline Right & 4 & 22 & 17 & $103 \pm 9$ & $4.3 \pm 0.2$ & $23.9 \pm 1.0$ \\
\hline Left & 4 & 19 & 11 & $111 \pm 12$ & $4.8 \pm 0.6$ & $23.7 \pm 1.5$ \\
\hline Total & 8 & 41 & 28 & $106 \pm 7$ & $4.5 \pm 0.3$ & $23.8 \pm 0.8$ \\
\hline \multicolumn{7}{|l|}{$\mathrm{N} \mathrm{d} 11$} \\
\hline Right & 4 & 24 & 24 & $396 \pm 13$ & $41.7 \pm 3.1$ & $10.2 \pm 0.5$ \\
\hline Left & 4 & 22 & 19 & $383 \pm 23$ & $43.6 \pm 5.6$ & $10.9 \pm 1.2$ \\
\hline Total & 8 & 46 & 43 & $390 \pm 13$ & $42.5 \pm 3.0$ & $10.5 \pm 0.6$ \\
\hline \multicolumn{7}{|l|}{$\mathrm{MD}$ d 11} \\
\hline Right & 5 & 27 & 22 & $342 \pm 20^{* *}$ & $30.2 \pm 2.4^{* * *}$ & $11.8 \pm 0.6^{*}$ \\
\hline Left & 5 & 29 & 24 & $327 \pm 22^{* *}$ & $28.2 \pm 2.3^{* * *}$ & $12.0 \pm 0.4^{*}$ \\
\hline Total & 10 & 56 & 46 & $334 \pm 15^{* *}$ & $29.2 \pm 1.7^{* * *}$ & $11.9 \pm 0.3^{*}$ \\
\hline \multicolumn{7}{|l|}{$\mathrm{N} \mathrm{d} 12$} \\
\hline Right & 5 & 32 & 31 & $1133 \pm 34$ & $244.4 \pm 7.5$ & $4.7 \pm 0.1$ \\
\hline Left & 5 & 24 & 23 & $1208 \pm 31$ & $238.8 \pm 7.7$ & $5.2 \pm 0.2$ \\
\hline Total & 10 & 56 & 54 & $1165 \pm 24$ & $242.0 \pm 5.4$ & $4.9 \pm 0.1$ \\
\hline \multicolumn{7}{|l|}{$\mathrm{MD} d 12$} \\
\hline Right & 4 & 28 & 20 & $940 \pm 93 * *$ & $168.6 \pm 16.8^{* * *}$ & $6.4 \pm 0.7^{*}$ \\
\hline Left & 4 & 21 & 17 & $980 \pm 104^{* *}$ & $177.2 \pm 20.7^{* * *}$ & $5.8 \pm 0.3^{*}$ \\
\hline Total & 8 & 49 & 37 & $958 \pm 68^{* *}$ & $172.5 \pm 13.0^{* * *}$ & $6.1 \pm 0.4^{*}$ \\
\hline
\end{tabular}

Significances:

$* p<0.05$ vs $\mathrm{N}$.

${ }^{* *} p<0.01 v s \mathrm{~N}$.

*** $p<0.001$ vs $\mathrm{N}$ (two-tailed $t$ test).

Table 3. Outcome of pregnancy in the whole $N$ and $M D$ groups

\begin{tabular}{lcccccccc}
\hline & $\begin{array}{c}\text { No. of uterine } \\
\text { horns }\end{array}$ & $\begin{array}{c}\text { No. of } \\
\text { implantations }\end{array}$ & $\begin{array}{c}\text { No. of } \\
\text { resorptions }\end{array}$ & $\begin{array}{c}\text { Percent } \\
\text { resorptions }\end{array}$ & $\begin{array}{c}\text { No. of viable } \\
\text { offspring }\end{array}$ & $\begin{array}{c}\text { No. of viable } \\
\text { offspring (d 11-12) }\end{array}$ & $\begin{array}{c}\text { No. of } \\
\text { malformations }\end{array}$ & $\begin{array}{c}\text { Percent } \\
\text { malformation }\end{array}$ \\
\hline N right & 31 & 195 & 10 & 5.1 & 185 & 94 & 4 & 4.3 \\
N left & 31 & 170 & 11 & 6.5 & 159 & 81 & 4 & 4.9 \\
N total & 62 & 365 & 21 & 5.8 & 344 & 175 & 72 & 26 \\
MD right & 27 & 170 & 32 & $18.8^{* * *}$ & 138 & 54 & $36.1^{* * *}$ \\
MD left & 27 & 137 & 31 & $22.6^{* * *}$ & 106 & 126 & $40.7^{* * *}$ \\
MD total & 54 & 307 & 63 & $20.5^{* * *}$ & 244 & 126 & 48 \\
\hline
\end{tabular}

Resorption rate is calculated as percentage of the number of implantations. The malformation rate is calculated in percent of the number of viable (nonresorbed) embryos. Statistical comparisons are made between the number of resorptions and malformations in the $\mathrm{N}$ and MD groups ( $\chi^{2}$ statistics with Yates' correction). Significances:

${ }^{*} p<0.05$ vs $\mathrm{N}$

$* * p<0.01$ vs $\mathrm{N}$.

*** $p<0.001$ vs $\mathrm{N}$

embryos from d 10-12, and in the whole egg cylinder of concepti from $d 9$. Subsequent to the morphologic scoring the embryos were homogenized (Ultrasonic, MSE, London, UK) in $0.5-1 \mathrm{~mL}$ of $0.5 \mathrm{M} \mathrm{NaOH}$. The protein content of the homogenates was determined by the method of Lowry et al. (23) using BSA as a standard, and DNA was measured as described by Kissane and Robins (24) and Hinegardner (25).

Estimation of uterine blood flow. Pregnant $\mathrm{N}$ and $\mathrm{MD}$ females were anesthetized on gestational d $9,10,11$, or 12 with an intraperitoneal dose of $60 \mathrm{mg} / \mathrm{kg}$ pentobarbital (Mebumal, Nordvacc AB, Solna, Sweden), heparinized, and placed on an operating table maintained at body temperature. Polyethylene catheters were inserted into the ascending aorta via the right carotid artery and into the abdominal aorta via the left femoral artery. The body temperature was registered by a rectal thermistor probe, and the mean arterial blood pressure was monitored by a pressure transducer (PDCR 75/1; Druck, Groby, UK) connected to an arterial catheter. Nonradioactive micro- 
Table 4. Outcome of pregnancy in the $N$ and $M D$ animals of different gestational age

\begin{tabular}{|c|c|c|c|c|c|c|c|c|c|c|}
\hline & $\begin{array}{l}\text { No. of uterine } \\
\text { horns }\end{array}$ & $\begin{array}{c}\text { No. of } \\
\text { implantations }\end{array}$ & $\begin{array}{l}\text { Implantations } \\
\text { per horn }\end{array}$ & $\begin{array}{l}\text { No. of } \\
\text { resorptions }\end{array}$ & $\begin{array}{l}\text { Resorptions } \\
\text { per horn }\end{array}$ & $\begin{array}{l}\text { Percent } \\
\text { resorptions }\end{array}$ & $\begin{array}{c}\text { No. of viable } \\
\text { offspring }\end{array}$ & $\begin{array}{c}\text { No. of } \\
\text { malformations }\end{array}$ & $\begin{array}{l}\text { Malformations } \\
\text { per horn }\end{array}$ & $\begin{array}{c}\text { Percent } \\
\text { malformations }\end{array}$ \\
\hline \multicolumn{11}{|l|}{$\mathrm{N}$ d 9} \\
\hline Right & 7 & 45 & $6.4 \pm 0.8$ & 3 & $0.4 \pm 0.2$ & 6.7 & & & & \\
\hline Left & 7 & 38 & $5.4 \pm 0.7$ & 2 & $0.3 \pm 0.3$ & 5.3 & & & & \\
\hline Total & 14 & 83 & $5.9 \pm 0.5$ & 5 & $0.4 \pm 0.2$ & 6.0 & & & & \\
\hline \multicolumn{11}{|l|}{ MD d 9} \\
\hline Right & 7 & 40 & $5.7 \pm 0.5$ & 9 & $1.3 \pm 0.5$ & $22.5^{* * *}$ & & & & \\
\hline Left & 7 & 39 & $5.6 \pm 0.5$ & 8 & $1.1 \pm 0.5$ & $20.5^{* * *}$ & & & & \\
\hline Total & 14 & 79 & $5.6 \pm 0.3$ & 17 & $1.2 \pm 0.3$ & $21.5^{* * *}$ & & & & \\
\hline \multicolumn{11}{|l|}{$\mathrm{N} \mathrm{d} 10$} \\
\hline Right & 8 & 45 & $5.5 \pm 0.7$ & 4 & $0.5 \pm 0.3$ & 8.9 & & & & \\
\hline Left & 8 & 40 & $5.0 \pm 1.0$ & 2 & $0.3 \pm 0.2$ & 5.0 & & & & \\
\hline Total & 16 & 85 & $5.3 \pm 0.6$ & 6 & $0.3 \pm 0.2$ & 7.1 & & & & \\
\hline \multicolumn{11}{|l|}{ MD d 10} \\
\hline Right & 7 & 42 & $6.3 \pm 0.8$ & 12 & $1.7 \pm 0.6$ & $28.6^{* * *}$ & & & & \\
\hline Left & 7 & 32 & $4.6 \pm 0.5$ & 13 & $2.0 \pm 0.6$ & $40.6^{* * *}$ & & & & \\
\hline Total & 14 & 76 & $5.4 \pm 0.5$ & 25 & $1.9 \pm 0.4$ & $32.9^{* * *}$ & & & & \\
\hline \multicolumn{11}{|l|}{ N d 11} \\
\hline Right & 8 & 52 & $6.5 \pm 0.9$ & 2 & $0.3 \pm 0.2$ & 3.9 & 50 & 1 & $0.1 \pm 0.1$ & 2.0 \\
\hline Left & 8 & 50 & $6.3 \pm 0.8$ & 5 & $0.6 \pm 0.3$ & 10.0 & 45 & 3 & $0.4 \pm 0.3$ & 6.7 \\
\hline Total & 16 & 102 & $6.4 \pm 0.6$ & 7 & $0.4 \pm 0.2$ & 6.9 & 95 & 4 & $0.3 \pm 0.1$ & 4.2 \\
\hline \multicolumn{11}{|c|}{ MD d 11} \\
\hline Right & 9 & 52 & $5.8 \pm 0.7$ & 4 & $0.4 \pm 0.2$ & 7.9 & 48 & 16 & $1.8 \pm 0.4^{* * *}$ & $33.3^{* * *}$ \\
\hline Left & 9 & 46 & $5.1 \pm 0.4$ & 8 & $0.9 \pm 0.3$ & 17.4 & 38 & 15 & $1.7 \pm 0.4^{* * *}$ & $39.5^{* * *}$ \\
\hline Total & 18 & 98 & $5.4 \pm 0.4$ & 12 & $0.7 \pm 0.2$ & 12.3 & 86 & 31 & $1.7 \pm 0.3^{* * *}$ & $36.1^{* * *}$ \\
\hline \multicolumn{11}{|l|}{$\mathrm{N} \mathrm{d} 12$} \\
\hline Right & 8 & 53 & $6.6 \pm 0.5$ & 1 & $0.1 \pm 0.1$ & 1.9 & 52 & 4 & $0.5 \pm 0.4$ & 7.7 \\
\hline Left & 8 & 42 & $5.3 \pm 0.5$ & 1 & $0.1 \pm 0.1$ & 2.4 & 41 & 1 & $0.1 \pm 0.1$ & 2.4 \\
\hline Total & 16 & 95 & $5.9 \pm 0.4$ & 2 & $0.1 \pm 0.1$ & 2.1 & 93 & 5 & $0.3 \pm 0.2$ & 5.4 \\
\hline \multicolumn{11}{|l|}{ MD d 12} \\
\hline Right & 7 & 50 & $7.1 \pm 0.6$ & 12 & $1.7 \pm 0.8^{* * *}$ & $24.0^{* * *}$ & 38 & 15 & $2.1 \pm 0.6^{*}$ & $39.5 * * *$ \\
\hline Left & 7 & 36 & $5.1 \pm 0.3$ & 8 & $1.1 \pm 0.4^{* * *}$ & $22.2^{* * *}$ & 28 & 13 & $1.9 \pm 0.5^{* *}$ & $46.4 * * *$ \\
\hline Total & 14 & 86 & $61.1 \pm 0.4$ & 20 & $1.4 \pm 0.4^{* * *}$ & $23.3^{* * *}$ & 66 & 28 & $2.0 \pm 0.4^{* * *}$ & $42.4^{* * *}$ \\
\hline
\end{tabular}

Resorptions and malformations are calculated in percent of the number of implanted and viable embryos, respectively. Implantations, resorptions, and malformations per horn are expressed as mean \pm SEM. Significances:

$* p<0.05$ vs N.

$* * p<0.01$ vs $\mathrm{N}$.

${ }^{* * *} p<0.001$ vs N (two-tailed $t$ test and $\chi^{2}$ statistics with Yates' correction).

spheres with a mean diameter of $11 \mu \mathrm{m}$ (NEN-Trac, Dupont Pharmaceuticals Inc., Wilmington, DE) were injected into the arterial circulation, and a reference sample was collected for 1 min. The pregnant rat was subsequently killed by decapitation, and the uterine horns were dissected out. Each uterine horn was then divided into segments, each containing one implantation site surrounded by intact decidua and uterine tissue. Each uterine segment was carefully dissected further to yield three samples: uterine wall, decidua, and conceptus (judged to be a resorbed, viable nonmalformed, or viable malformed embryo). The pieces of uterine wall and decidual tissue were weighed immediately and placed between two glass slides in accordance with the technique described by Eriksson and Jansson (7). After morphologic inspection, the embryos were also placed between glass slides. The number of microspheres in the tissue and the reference samples were counted in an inverted stereo microscope at a magnification of $40 \times$.

Using the blood flow in the reference sample, estimated by weighing, the number of microspheres could be converted to total blood flow $(\mathrm{mL} / \mathrm{min})$ and relative blood flow $(\mathrm{mL} / \mathrm{min} \cdot \mathrm{g})$ in the uterine and decidual tissue samples.
Statistics. The study consisted of two series of pregnant N and MD animals. In the first series the embryonic crown-rump length, somite number, as well as protein and DNA contents were estimated (see Tables 1 and 2). In the other series the blood flow was measured with the microsphere technique, which did not allow the determination of these variables, because the embryos were processed together with decidua and uterine tissue (see Table 5). Some embryonic data, however, were collected from both series-number and percent implantations, resorptions, and malformations-and were therefore pooled (see Tables 3 and 4). Data are given as mean \pm SEM. Statistical inferences were based on a two-tailed $t$ test for mean values or $\chi^{2}$ statistics with Yates' correction for proportions of resorptions and malformations (26).

\section{RESULTS}

Embryonic outcome in the different age groups are shown in Table 1 . The MD offspring had significantly smaller crownrump length than the $\mathrm{N}$ offspring on gestational d 10-12, and fewer somites on d 12. Also, the MD offspring contained less 


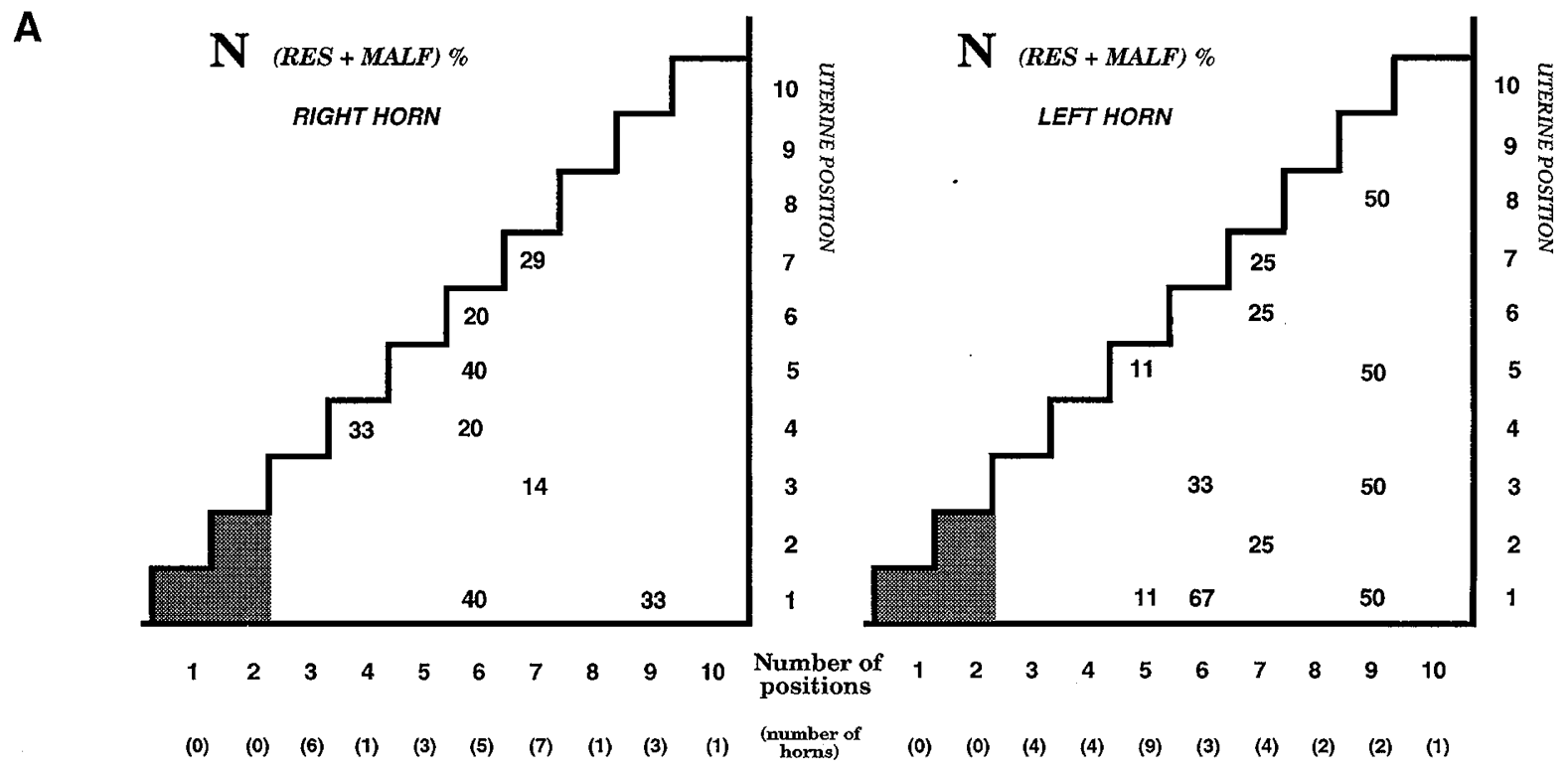

B

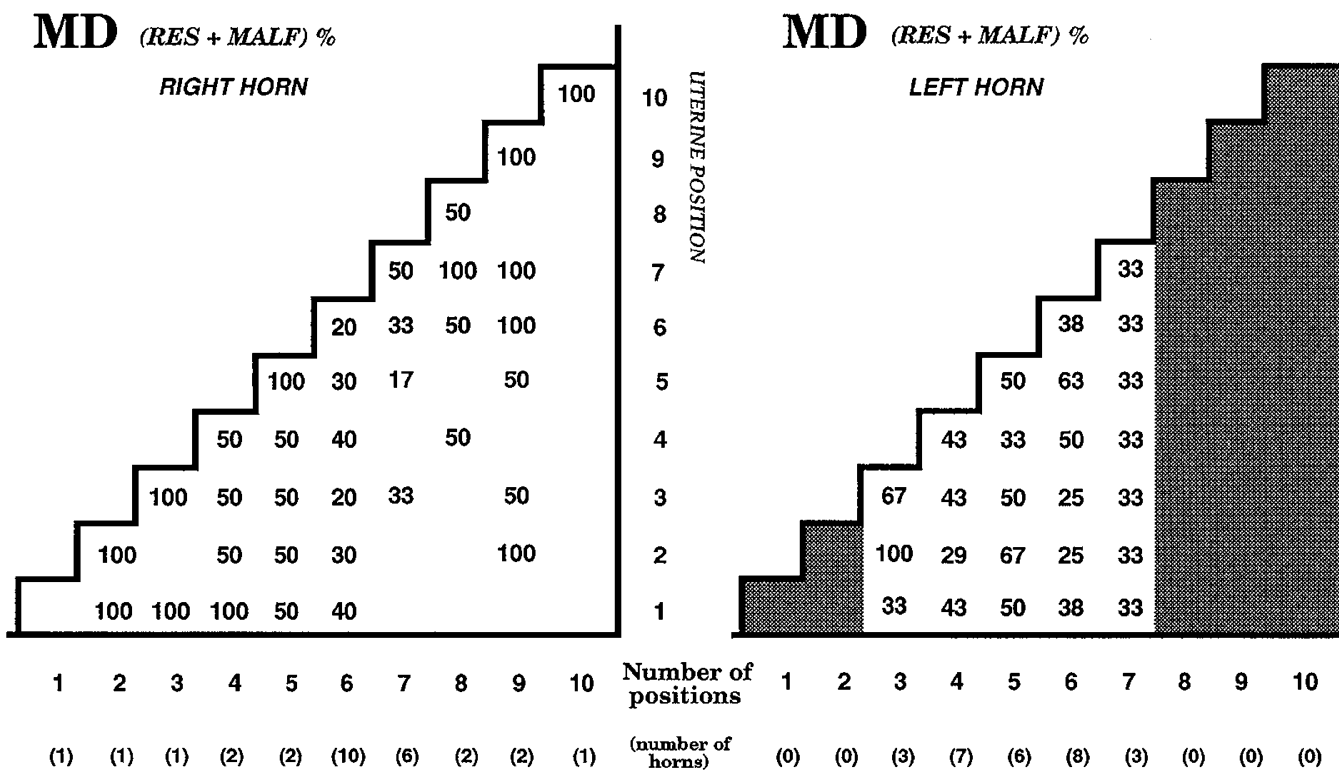

Figure 1. (A) Distribution of resorbed or malformed embryos in the right or left uterine horn of $\mathrm{N}$ pregnant rats. Each number in the diagrams represents the sum of resorbed + malformed embryos in percent of the total amount of implantations at a particular uterine position. No number at all indicates that all embryos at this position are normal. The uterine positions are numbered consecutively from the implantation site nearest the ovary (which is $=1$ ), as shown on the $y$ axis. The uterine horns are classified with regard to their total number of implantations, as displayed on the $x$ axis (denoted Number of positions), where also the sum of horns in each group is shown in parentheses. Example: there are five right horns with exactly six implantations, which means that there are a total of five implantations at each position in the " 6 " column of the left figure. Furthermore, in positions 1, 4, 5, and 6 of the "6" column there are resorptions/malformations, and in positions 2 and 3 there are none. In positions 1 and 5 there are 2 resorptions/malformations out of the total number of five implantations (yields $40 \%$ ), in positions 4 and 6 there is only 1 resorbed/malformed offspring of 5 implantations (20\%). (B) Distribution of resorbed or malformed embryos in the right or left uterine horn of MD pregnant rats. Each number in the diagrams represents the sum of resorbed + malformed embryos in percent of the total amount of implantations at a particular uterine position. No number at all indicates that all embryos at this position are normal. The uterine positions are numbered consecutively from the implantation site nearest the ovary (which is $=1$ ), as shown on the $y$ axis. The uterine horns are classified with regard to their total number of implantations, as displayed on the $x$ axis (denoted "number of positions"), where also the sum of horns in each group is shown in parenthesis. Example: there are six right horns with exactly seven implantations, which means that there are a total of six implantations at each position in the " 7 " column of the left figure. Furthermore, in positions 3,5,6, and 7 of the " 7 " column there are resorptions/malformations, and in positions 1, 2, and 4 there are none. In positions 3 and 6 there are 2 resorptions/malformations out of the total number of six implantations (yields 33\%), in position 5 there is only 1 resorbed/malformed offspring of six implantations (17\%), and in position 7 half of the implantations (three of six, i.e. 50\%) are malformed or resorbed.

protein and DNA than the $\mathrm{N}$ offspring on gestational d 11-12. This decrease was not symmetrical, because the protein/DNA ratio in the MD embryos was increased compared with the ratio of the $\mathrm{N}$ embryos on the same days (Table 2).

The total distribution of resorptions and malformations among the offspring is displayed in Table 3. The MD horns had more resorptions and malformations than the $\mathrm{N}$ horns, expressed as percent of implantations and viable offspring, respectively. The number of implantations per horn tended to be higher in the right horns, both in the N and MD group, but this finding did not reach statistical significance. Likewise, the numerical values of resorption and malformation percentages 
Table 5. Blood flow in uterine and decidual tissue in $N$ and $M D$ animals of different gestational ages, estimated as $\mathrm{ml} / \mathrm{min} \cdot \mathrm{g}$

\begin{tabular}{|c|c|c|c|c|}
\hline & $\begin{array}{l}\text { No. of } \\
\text { uterine } \\
\text { horns }\end{array}$ & $\begin{array}{l}\text { Implantations } \\
\text { per horn }\end{array}$ & $\begin{array}{c}\text { Uterine blood } \\
\text { flow }\end{array}$ & $\begin{array}{l}\text { Decidual blood } \\
\text { flow }\end{array}$ \\
\hline \multicolumn{5}{|l|}{$\mathrm{Nd} 9$} \\
\hline Right & 3 & $8.3 \pm 0.7$ & $0.36 \pm 0.05$ & $0.14 \pm 0.02$ \\
\hline Left & 3 & $6.7 \pm 0.9$ & $0.30 \pm 0.05$ & $0.14 \pm 0.03$ \\
\hline Total & 6 & $7.5 \pm 0.6$ & $0.33 \pm 0.04$ & $0.14 \pm 0.02$ \\
\hline \multicolumn{5}{|l|}{$\mathrm{MD} d 9$} \\
\hline Right & 3 & $6.0 \pm 0.0$ & $0.80 \pm 0.15^{* * *}$ & $0.50 \pm 0.06^{* * *}$ \\
\hline Left & 3 & $6.3 \pm 0.8$ & $0.58 \pm 0.12 * * *$ & $0.48 \pm 0.08^{* * *}$ \\
\hline Total & 6 & $6.2 \pm 0.3$ & $0.69 \pm 0.10^{* * *}$ & $0.49 \pm 0.05^{* * *}$ \\
\hline \multicolumn{5}{|l|}{$\mathrm{N} \mathrm{d} 10$} \\
\hline Right & 3 & $4.7 \pm 2.0$ & $1.09 \pm 0.28$ & $0.17 \pm 0.04$ \\
\hline Left & 3 & $5.7 \pm 3.0$ & $1.06 \pm 0.18$ & $0.18 \pm 0.03$ \\
\hline Total & 6 & $5.2 \pm 1.6$ & $1.07 \pm 0.16$ & $0.17 \pm 0.03$ \\
\hline \multicolumn{5}{|l|}{ MD d } \\
\hline \multicolumn{5}{|l|}{10} \\
\hline Right & 3 & $7.3 \pm 1.8$ & $2.24 \pm 0.37^{* * *}$ & $0.44 \pm 0.08 * * *$ \\
\hline Left & 3 & $4.3 \pm 0.9$ & $4.48 \pm 0.94 * * *$ & $0.71 \pm 0.14^{* * *}$ \\
\hline Total & 6 & $5.0 \pm 1.3$ & $2.99 \pm 0.44 * * *$ & $0.53 \pm 0.07 * * *$ \\
\hline \multicolumn{5}{|l|}{$\mathrm{N} \mathrm{d} 11$} \\
\hline Right & 4 & $7.0 \pm 1.2$ & $0.34 \pm 0.03$ & $0.05 \pm 0.01$ \\
\hline Left & 4 & $7.0 \pm 0.9$ & $0.27 \pm 0.02$ & $0.06 \pm 0.01$ \\
\hline Total & 8 & $7.0 \pm 0.7$ & $0.31 \pm 0.02$ & $0.06 \pm 0.01$ \\
\hline \multicolumn{5}{|l|}{$\mathrm{MD} \mathrm{d}$} \\
\hline \multicolumn{5}{|l|}{11} \\
\hline Right & 4 & $6.3 \pm 1.3$ & $0.89 \pm 0.10^{* * *}$ & $0.14 \pm 0.02 * * *$ \\
\hline Left & 8 & $4.3 \pm 0.5$ & $0.84 \pm 0.12 * * *$ & $0.12 \pm 0.02 * * *$ \\
\hline Total & 8 & $5.3 \pm 0.7$ & $0.87 \pm 0.08 * * *$ & $0.13 \pm 0.01^{* * *}$ \\
\hline \multicolumn{5}{|l|}{$\mathrm{N} \mathrm{d} 12$} \\
\hline Right & 3 & $7.0 \pm 1.2$ & $0.59 \pm 0.05$ & $0.06 \pm 0.01$ \\
\hline Left & 3 & $6.0 \pm 0.6$ & $0.39 \pm 0.04$ & $0.04 \pm 0.01$ \\
\hline Total & 6 & $6.5 \pm 0.6$ & $0.50 \pm 0.04$ & $0.05 \pm 0.01$ \\
\hline \multicolumn{5}{|l|}{$\mathrm{MD} d$} \\
\hline 12 & & & & \\
\hline Right & 3 & $7.3 \pm 1.2$ & $1.35 \pm 0.23^{* * *}$ & $0.08 \pm 0.01^{* * *}$ \\
\hline Left & 3 & $5.0 \pm 0.6$ & $2.33 \pm 0.50^{* * *}$ & $0.10 \pm 0.01^{* * *}$ \\
\hline Total & 6 & $6.2 \pm 0.8$ & $1.75 \pm 0.26^{* * *}$ & $0.09 \pm 0.01^{* * *}$ \\
\hline
\end{tabular}

The data are expressed as mean \pm SEM. Significances:

$* p<0.05$ vs $\mathrm{N}$.

** $p<0.01$ vs $\mathrm{N}$.

${ }_{* * *} p<0.001$ vs $\mathrm{N}$ (two-tailed $t$ test).

were greater in the left horns compared with the figures of the right horns in both the $\mathrm{N}$ and MD rats, again without reaching statistical significance.

Table 4 gives detailed information regarding embryonic outcome in right and left uterine horns of $\mathrm{N}$ and MD pregnancies from all experimental groups. The previous trends of slightly more implantations in the right horns, and more resorptions and malformations in the left horns were again seen in the different groups, again without clear-cut statistical significancies. Resorption percentage was increased in $\mathrm{MD}$ pregnancies on $\mathrm{d} 9,10$, and 12 , whereas the malformation percentage was increased both on $\mathrm{d} 11$ and 12 (Table 4).

The distribution of resorptions and malformations in uterine horns of different sizes is shown in Figure $1, A$ and $B$. In general, a tendency to clustering of these dysmorphogenic events to the lateral edges of each horn was seen in the $\mathrm{N}$ pregnancies (Fig. 1A). In the MD litters, a similar type of lateral clustering was found, and the dysmorphogenesis was more pronounced in the horns with fewer implantations (Fig. $1 B)$.

The mean uterine and decidual blood flow per implantation site in right and left uterine horns of $\mathrm{N}$ and MD litters is shown in Table 5. Both the flow in the uterine wall and the decidual tissue of the MD pregnancies were increased in comparison with the $\mathrm{N}$ pregnancies. Within each experimental group the flow was increased on d 10 compared with d 9 , decreased back to $d 9$ levels on $d 11$, and increased again on d 12 (Table 5). On d 10 and 12, the days with the highest blood flow in both groups, there was a clear tendency to increased flow in the left horns of the MD group (Table 5). We never encountered microspheres in the embryos, thus indicating that there was no transfer of maternal blood to the fetal circulation in normal and diabetic rats during gestational d 9-12.

Figure 2, $A-D$, shows the uterine blood flow in $\mathrm{N}$ and $\mathrm{MD}$ pregnancies with respect to position index. The MD pregnancies showed higher flow in general, as expected, but no clear gradient in the flow values with respect to the middle or lateral ends of the horns could be discerned in either $\mathrm{N}$ or MD rats.

The blood flow in the uterine and decidual tissue of the $\mathrm{N}$ rats did not differ if the offspring was viable or nonviable (Fig. $3, A$ and $B$ ). In contrast, both the uterine and decidual tissue of the nonviable implantation sites of the MD d 9 pregnancies showed increased blood flow compared with the flow in these tissues surrounding viable $\mathrm{MD}$ offspring (Fig. 3, $A$ and $B$ ). Furthermore, both the decidua and uterine tissue of the MD d 10 nonviable implantations had decreased blood flow in comparison with the viable implantations (Fig. 3, $A$ and $B$ ).

\section{DISCUSSION}

The major finding in this study was the increased blood flow in the uterine and decidual tissue of the pregnant diabetic animals on all days compared. The increment was more pronounced in the uterine tissue than in the decidual tissue on $d$ $9-10$, and this pattern was reversed in the $\mathrm{d} 11$ and 12 tissues. The finding of different flow patterns may indicate that these blood flows are independently regulated, although both are stimulated by maternal diabetes. In addition, both types of blood perfusions peaked on gestational d 10, both in normal and diabetic pregnancy. The findings of increased general blood flow in diabetes, confirming previous results $(27,28)$, as well as the similar development of the blood flow in the normal and diabetic tissues with time, suggest that the developing conceptus in the diabetic environment has access to ample amounts of nutrients, among them also oxidative substrates (e.g. glucose, ketone bodies, branched chain amino acids) at a time period when alterations in the embryonic development are induced, i.e. during the teratologic period $(13,14)$.

The biphasic response in uterine and decidual blood flow with a peak value at $d 10$, and then a decline is intriguing. One possible explanation could be that many new blood vessels are formed until $d 10$, and that these immature vessels initially contain only small amounts of regulatory mechanisms. It has recently been suggested that organs with rapidly developing vasculature, such as the corpus luteum, do not regulate their own blood flow (29). Instead blood perfusion of surrounding 

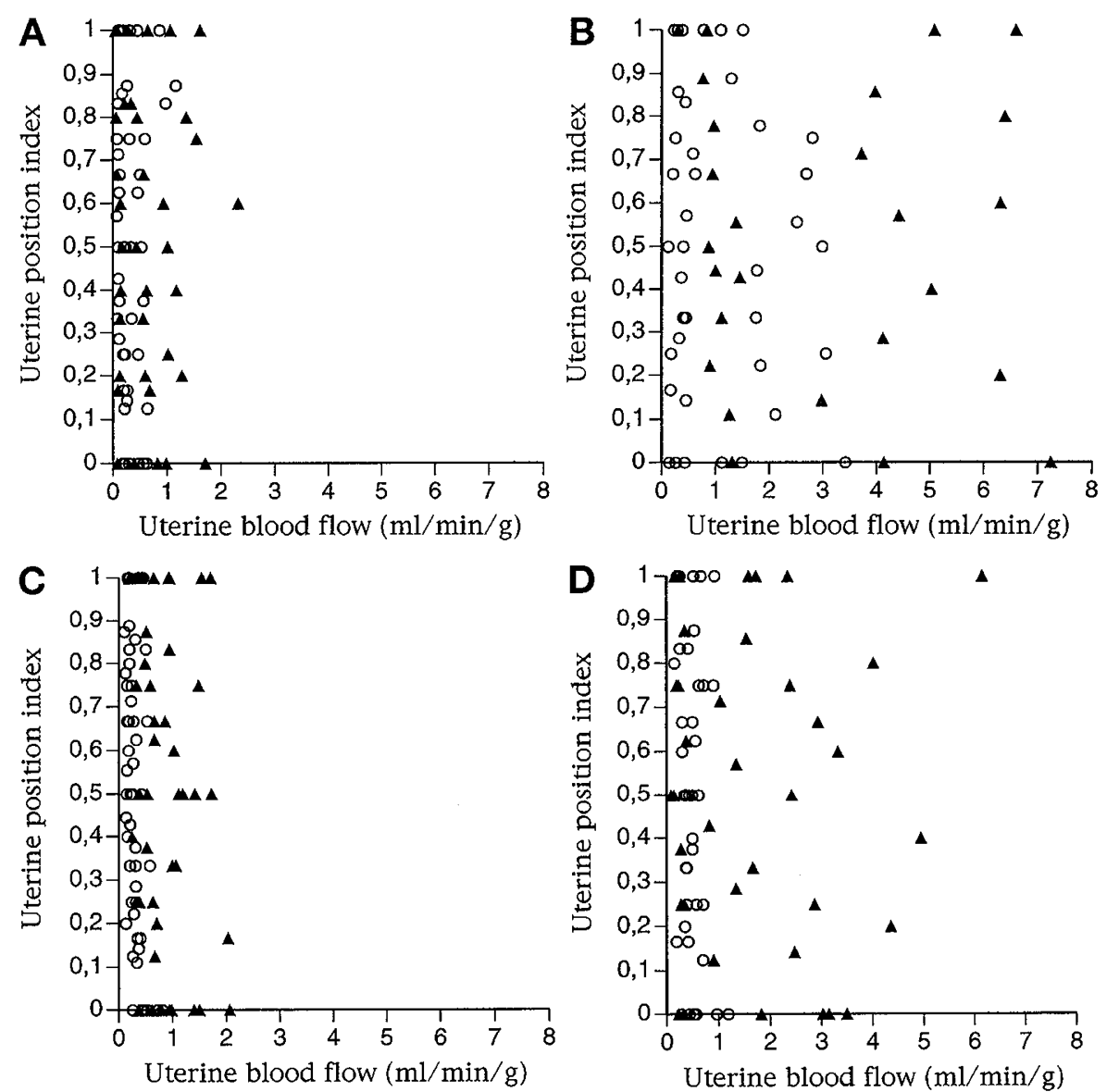

Figure 2. $(A-D)$ Uterine blood flow in relation to position index ( $c f$. Methods) in $\mathrm{N}(\mathrm{O})$ and $\mathrm{MD}(\mathbf{\Delta})$ rat pregnancy on gestational d $9(A)$, d $10(B)$, d $11(C)$, and $\mathrm{d} 12(D)$.

tissues is regulated, whereas the organ with immature blood vessels passively receives the blood remaining. This is analogous to mechanisms suggested to operate within malignant tumors (30) and transplanted cell aggregates $(31,32)$, which also contain immature microvessels. If so, the present findings of a decreased uterine and decidual blood flow on $\mathrm{d} 11$ and 12 could reflect a maturation and acquisition of an independent blood flow regulation. No morphologic studies supporting this notion are presently available.

It should be noted in this context that chronic hyperglycemia of a few weeks duration, which was seen in the diabetic animals in this study, is associated with a general hyperperfusion with blood (27). An increased blood flow to organ parts which have a limited capacity to regulate their blood flow, would be expected to cause a selective increase in that region. It is also known that experimentally induced diabetes per se affects the microvascular reactivity of rats $(28,33-35)$, which may also affect the blood flow regulation differently in mature and immature blood vessels. Diabetes-induced alterations in the regulation of blood flow were found in the present study on gestational $\mathrm{d} 9$ and 10 , manifested as marked differences in the perfusion of viable and nonviable implantations and surrounding uterine tissue in the MD rats, in contrast to the absence of any such changes in the pregnant $\mathrm{N}$ rats. The significance of these blood flow alterations for the incidence of resorptions and other disturbances of embryonic development-i.e. increased blood flow on d 9 and decreased on d 10-remains to be elucidated.

In this context it is worthy to note that, in a recent experimental study, a correlation was found between increased maternal concentrations of glucose, $\beta$-hydroxybutyrate, and branched chain amino acids, and increased risk for embryonic maldevelopment in rat diabetic pregnancy (36). This finding may lend support to the concept of increased delivery of oxidative substrates to the embryo as a teratologic mechanism in diabetic pregnancy.

The increased blood flow in the uterodecidual tissue in the pregnant diabetic rats resembles the renal hyperfiltration found in diabetic rats, which is, at least partly, dependent on increased production of the endogenous vasodilator, nitric oxide (NO) (37). Future evaluation of the NO production in uterodecidual tissues may prove to be of great interest.

The other major questions promoting this study, whether there are any correlations between uterine position, embryonic status, and blood flow to the implantation site, were answered in different ways by the present study. Thus, we found a tendency toward fewer implantations in the left horn than in the. right horn, concomitant with slightly increased resorption rate and malformation rate in the left horn. These findings implicate the left horn as a site of suboptimal growth and development, particularly when pregnancy is complicated by maternal diabetes. Recently, a supporting report was published, showing 

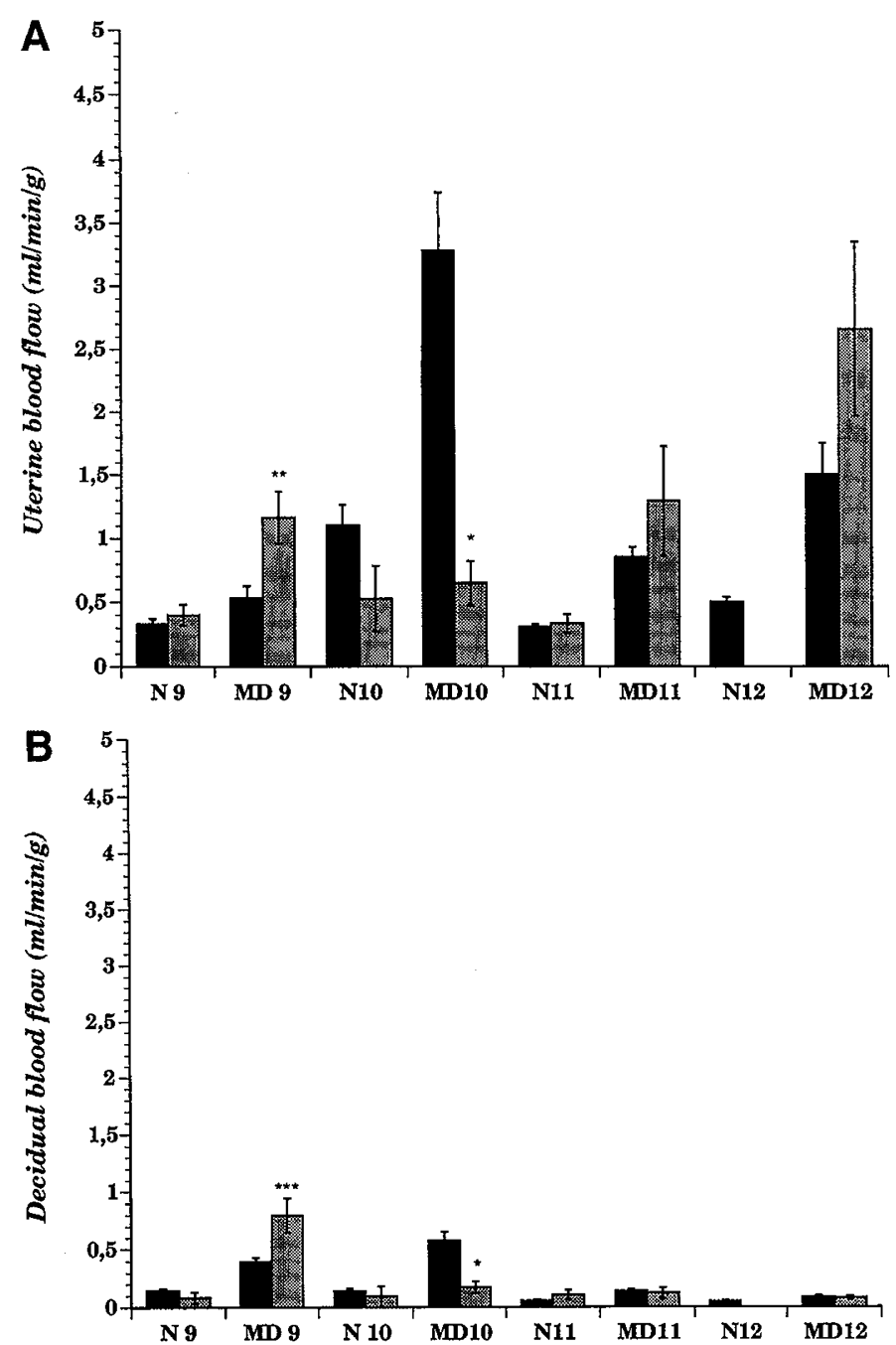

Figure 3. $(A$ and $B$ ) Mean blood flow in uterine $(A)$ and decidual $(B)$ tissue from offspring of $\mathrm{N}$ and $\mathrm{MD}$ rat pregnancy divided among viable ( $\mathbf{D}$ ) and nonviable (羂) offspring. Data are given as mean \pm 9 SEM. Significancies: ${ }^{*} p$ $<0.05 v s$ viable embryos of same age, ${ }^{* *} p<0.01$ vs viable embryos of same age, ${ }^{* *} p<0.001$ vs viable embryos of same age.

decreased blood flow to the left uterine horn of normal SpragueDawley rats in early pregnancy (20). The blood flows in the uterine and decidual tissues of diabetic rats in the present study, however, were increased in the left horn both on $\mathrm{d} 10$ and 12 , thereby suggesting that compromised embryonic development is associated with increased rather than decreased supply of nutrients to the implantation site.

When the embryonic development was correlated to the uterine position per se we found a pattern with more malformations and resorptions toward the ends of the horns. This may, again, be related to nutrient supply, because the feeding arteries enter the horns from both ends (38). The actual perfusion, however, showed only a weak tendency to increased blood flow in the outer portions of the horns. Again, there has been a recent study report in which the outer portions of the horns of pregnant Sprague-Dawley rats received more blood supply than the middle portions of the horns (20).

In conclusion, the presented data support the view that increased substrate availability is associated with increased embryonic risk of maldevelopment in diabetic pregnancy.
Acknowledgments. The authors thank Drs. Martin Simán and Richard Schnell, Department of Medical Cell Biology, who assisted in the analysis of the large amount of data.

\section{REFERENCES}

1. Nylund L, Lunell NO, Lewander R, Persson B, Sarby B 1982 Uteroplacental blood flow in diabetic pregnancy: measurements with indium $113 \mathrm{~m}$ and a computer linked gamma camera. Am J Obstet Gynecol 144:298-302

2. Björk O, Persson B, Stangenberg M, Vaclavinkova V 1984 Spiral artery lesions in relation to metabolic control in diabetes mellitus. Acta Obstet Gynecol Scand 63:123-127

3. Björk O, Persson B 1982 The fetal arterial vasculature in placentas of insulindependent diabetic mothers. Acta Pathol Microbiol Immunol Scand 90:289-294

4. Teasdale F 1981 Histomorphometry of the placenta of the diabetic women: class A diabetes mellitus. Placenta 2:241-251

5. Teasdale F 1988 Histomorphometry of the human placenta in class B diabetes mellitus. Placenta 4:1-12

6. Björk O, Persson B 1984 Villous structure in different parts of the cotyledon in placentas of insulin-dependent diabetic women. A morphometric study. Acta Obstet Gynecol Scand 63:37-43

7. Eriksson UJ, Jansson L 1984 Diabetes in pregnancy: decreased placental blood flow and disturbed fetal development in the rat. Pediatr Res 18:735-738

8. Palacin M, Lasunción MA, Martin A, Herrera E 1985 Decreased uterine blood flow in the diabetic pregnant rat does not modify the augmented glucose transfer to the fetus. Biol Neonate 48:197-203

9. Chartrel NC, Clabaut MT, Boismare FA, Schrub J-C 1990 Uteroplacental hemodynamic disturbances in establishment of fetal growth retardation in streptozotocininduced diabetic rats. Diabetes 39:743-746

10. Prager R, Abramovici A, Liban E, Laron Z 1974 Histopathological changes in the placenta of streptozotocin induced diabetic rats. Diabetologia 10:89-91

11. Lasunción MA, Lorenzo J, Palacin M, Herrera E 1987 Maternal factors modulating nutrient transfer to fetus. Biol Neonate 51:86-93

12. Thomas CR, Eriksson GL, Eriksson UJ 1990 Effects of maternal diabetes on placental transfer of glucose in rats. Diabetes 39:276-282

13. Eriksson RSM, Thunberg L, Eriksson UJ 1989 Effects of interrupted insulin treatment on fetal outcome of pregnant diabetic rats. Diabetes 38:764-772

14. Mills J, Baker L, Goldman AS 1979 Malformations in infants of diabetic mothers occur before the seventh gestational week. Diabetes 28:292-293

15. Barr M, Jensh R, Brent R 1969 Fetal weight and intrauterine position in rats. Teratology 2:241-246

16. Barr M, Jensh R, Brent R 1970 Prenatal growth in the albino rat: effects of number, intrauterine position and resorptions. J Anat 128:413-428

17. Ward K, Karp C, Aceto H 1977 Developmental effects of the uterine environment: dependence on fetal sex in rats. J Reprod Fertil 50:269-274

18. Norman N, Bruce N 1979 Fetal and placental weight relationships at days 13 and 17 of gestation. J Reprod Fertil 57:345-348

19. Norman N, Bruce N 1979 Fetal and placental weight relationships in the albino rat near term. Teratology 19:245-250

20. Even MD, Laughlin MH, Krause GF, vom Saal FS 1994 Differences in blood flow to uterine segments and placentae in relation to sex, intrauterine location and side in pregnant rats. J Reprod Fertil 102:245-252

21. Garris DR 1988 Effect of diabetes on uterine condition, decidualization, vascularization and corpus luteum function in the pseudo pregnant rat. Endocrinology 122:665672

22. Eriksson UJ 1988 Importance of genetic predisposition and maternal environment for the occurrence of congenital malformations in offspring of diabetic rats. Teratology 37:365-374

23. Lowry OH, Rosenbrough NJ, Farr AL, Randall RJ 1951 Protein measurement with the folin phenol reagent. J Biol Chem 193:265-275

24. Kissane JM, Robins E 1958 The fluorometric measurement of deoxyribonucleic acid in animal tissues with special reference to the central nervous system. J Biol Chem 223:184-188

25. Hinegardner RT 1971 An improved fluorometric assay for DNA. Anal Biochem 39:197-201

26. Ostle B 1963 Statistics in Research, 2nd Ed. Iowa State University Press, Ames

27. Hill MA, Larkins RG 1989 Alterations in distribution of cardiac output in experimental diabetes in rats. Am J Physiol 257:H571-H580

28. Hill MA, Larkins RG 1989 Altered microvascular reactivity in streptozotocin-induced diabetes in rats. Am J Physiol 257:H1438-H1445

29. Wiltbank MC, Gallagher KP, Christensen AK, Brabec RK, Keyes PL 1990 Physiological and immunocytochemical evidence for a new concept of blood fiow regulation in the corpus luteum. Biol Reprod 42:139-149

30. Jain RK 1988 Determinants of tumor blood flow: a review. Cancer Res 48:26412658

31. Jansson L, Sandler S 1990 Altered blood flow regulation in autotransplanted pancreatic islets of rats. Am J Physiol 259:E52-E56

32. Jansson L, Sandler S 1992 The blood perfusion of transplanted pancreatic islets: evidence of a maturation of the blood-flow response to D-glucose with time after implantation. Transplantation 53:1368-1369

33. Christlieb AR 1974 Renin, angiotensin II and norepinephrine in alloxan diabetes. Diabetes 23:962-970 
34. Turlapaty PDMV, Lum G, Altura BM 1980 Vascular responsiveness and serum biochemical parameters in alloxan diabetes mellitus. Am J Physiol 239:E412E421

35. Jackson CV, Carrier GO 1983 Influence of short-term experimental diabetes on blood pressure and heart rate in response to norepinephrine and angiotensin $I I$ in the conscious rat. J Cardiovasc Pharmacol 5:260-265

36. Styrud J, Thunberg L, Nybacka O, Eriksson UJ 1995 Correlations between maternal metabolism and deranged development in the offspring of normal and diabetic rats. Pediatr Res 37:343-353

37. Tolins JP, Shultz PJ, Raij L, Brown DM, Mauer SM 1993 Abnormal renal hemodynamic response to reduced renal perfusion pressure in diabetic rats: role of NO. Am J Physiol 265:886-895

38. Nienartowicz A, Link S, Moll W 1989 Adaptation of the uterine arcade in rats to pregnancy. J Dev Physiol 12:101-108 